\title{
ANALISIS BIAYA EFEKTIF TERAPI SKABIES PERMETRIN 5\% DAN SALEP 2-4
}

\section{THERAPY OF SCABIES USING PERMETRIN 5\% COMPARED WITH UNGUENTUM 2-4 : A COST-EFFECTIVENESS ANALYSIS}

\author{
Handayani $N^{1}$, Ikaditya $L^{2}$ \\ 1,2 Poltekkes Kemenkes Tasikmalaya \\ Email : ${ }^{*}$ nurihandayani882@gmail.com, ${ }^{2}$ lingga.ikaditya@gmail.com
}

\begin{abstract}
ABSTRAK
Skabies merupakan penyakit yang disebabkan oleh infeksi Sarcoptes Scabiei. World Health Organization (WHO) memperkirakan angka kejadian di dunia yaitu 0,2-24\%, Indonesia mempunyai prevalensi skabies yang cukup tinggi dan cenderung tinggi pada anak-anak sampai dewasa. Penelitian ini bertujuan untuk melihat efektivitas terapi terhadap biaya antara pengobatan permetrin $5 \%$ dan salep 2-4. Penelitian ini merupakan uji klinis dengan pendekatan Cost Effectiveness Analysis (CEA). Populasi dalam penelitian ini adalah santri yang mengalami skabies di Pesantren Miftahul Huda. Metode pengambilan sampel yaitu total sampling sebanyak 21 Pasien. Hasil analisis dilihat berdasarkan Average Cost-Effectiveness Ratio (ACER) dan Incremental Cost-Effectiveness Ratio (ICER) menunjukkan bahwa penggunaan Salep 2-4 lebih efektif dibandingkan Salep Permetrin 5\%. Nilai ACER Salep 2-4 yaitu 521.978, sedangkan Salep Permetrin $5 \%$ yaitu 841.837. Nilai ICER yaitu 5.000 untuk peningkatan 1 unit efektivitas Permetrin terhadap Salep 2-4.
\end{abstract}

\section{Kata Kunci : Permetrin 5\%, Salep 24, Average Cost-Effectiveness Ratio, Incremental Cost- Effectiveness Ratio}

\begin{abstract}
Scabies is a skin disease caused by Sarcoptes scabiei infection. The World Health Organization (WHO) estimates that the world incidence is $0.2-24 \%$, Indonesia has a high prevalence of scabies, at any age. The object of this study is to compare the cost-effectiveness of permethrin 5\% with Unguentum $2-4$ in patients with scabies. The research type of this study is Cost-Effectiveness Analysis, the population in this study were students who diagnosed with scabies in Miftahul Huda Islamic boarding school. The sample recruited were 21 patients. The analysis of Average Cost Effectiveness (ACER) and Additional Cost Effectiveness Ratio (ICER) performed and show the use of Unguentum 2-4 is more effective than Permethrin $5 \%$. The score of ACER Unguentum 2-4 is 521,978 , while Permethrin $5 \%$ is 841,837 . ICER value is $R$ p. 5,000 for an increase of 1 unit effectivity of Permethrin $5 \%$ to Unguentum 2-4.
\end{abstract}

Keywords: Permethrin 5\%, Unguentum 2-4, ACER, ICER

DOI: $10.37160 /$ bmi.v15i2.432 


\section{PENDAHULUAN}

Skabies adalah penyakit yang disebabkan oleh infeksi Sarcoptes Scabiei, merupakan penyakit kulit yang terabaikan, dianggap biasa saja dan lumrah terjadi pada masyarakat di Indonesia, bahkan di dunia. Padahal tingkat prevalensi skabies ditinjau dari wilayah, usia maupun jenis kelamin relatif ada hampir di seluruh dunia dengan tingkat yang bervariasi. ${ }^{1}$ Tungau ektoparasit penyebab skabies adalah Sarcoptes scabiei var hominis termasuk ordo Acariformes, family Sarcoptidae, Genus Sarcoptes. Sarcoptes scabiei var hominis menular melalui kontak manusia dengan manusia ${ }^{2}$, sedangkan Sarcoptes scabiei var mange ditransmisikan ke manusia melalui kontak dengan berbagai hewan liar, hewan yang didomestikasi dan hewan ternak $^{3}$. Transfer tungau dari satu orang ke orang lain diperkirakan membutuhkan kontak dekat selama 15-20 menit. ${ }^{4}$ Saat ini istilah skabies berarti lesi kulit yang muncul oleh aktivitas tungau. ${ }^{5}$

Siswa pondok pesantren merupakan subjek penting dalam permasalahan skabies. Tinggal bersama dengan sekelompok orang di pondok pesantren memang berisiko mudah tertular berbagai penyakit terutama penyakit kulit. $^{6}$ Menurut Departemen Kesehatan RI 2008 prevalensi skabies di Indonesia sebesar 5,60$12,95 \%$ dan skabies menduduki urutan ketiga dari 12 penyakit kulit di Indonesia. ${ }^{6}$ World Health Organization (WHO) memperkirakan angka kejadian di dunia yaitu 0,2-24\%, kondisi ini lebih banyak menyerang daerah tropis, terutama meyerang anak-anak. ${ }^{7}$ Skabies menduduki peringkat ke-3 dari 12 penyakit tersering di Indonesia. ${ }^{8}$

Pengobatan penyakit skabies masih banyak menimbulkan resistensi dan efek samping obat. Selain itu adanya infeksi sekunder juga menimbulkan masalah yang lebih parah pada kulit, bahkan menyebabkan kematian. ${ }^{1}$ Terapi penyakit skabies kadang-kadang mengalami kegagalan atau pengobatan tidak bisa mencapai optimal sehingga kasus skabies masih ada. ${ }^{9}$ Obat-obatan untuk terapi topical skabies diantaranya sulfur, benzyl benzoate, allethrine, tiabendazol, krotamiton, monosulfiram, malation, lindane dan permethrine. Sebuah laporan penelitian menunjukkan bahwa telah terjadi resistensi dan berkurangnya efektivitas DOI: $10.37160 /$ bmi.v15i2.432 subscrisidal terhadap terapi skabies untuk mengobati reaksi inflamasi. ${ }^{8}$

Pengobatan skabies di Indonesia menggunakan permetrin $5 \%$ dan salep 2-4. Penelitian yang dilakukan Eka (2004) membandingkan efektivitas permetrin dengan salep 2-4 yang hasilnya adalah terdapat perbedaan jumlah penderita yang sembuh secara klinis antara pemberian permetrin 5\% dengan salep 2-4, namun uji statistik antara kelompok pengobatan tidak terdapat perbedaan yang bermakna. Penelitian yang dilakukan oleh Eka (2004) melihat keberhasilan terapi secara klinis, dari segi kefektifan biaya belum dilakukan. Untuk itu peneliti ingin mencoba mengkaji lebih dalam lagi, baik dari sisi ekonomi maupun dari klinis. Pengobatan skabies dengan krim permethrin $5 \%$ lebih praktis namun harga lebih mahal. Sedangkan pengobatan skabies dengan salep 2-4 lebih murah tetapi compliance penderita menurun. ${ }^{10}$

Permetrin 5\% dan salep 2-4, memilliki selisih biaya pengobatan yang cukup besar, karena harganyapun jauh berbeda permetrin 5\% lebih mahal hampir $100 \%$ dibandingkan dengan salep 2-4. Harga Scabimite (Permetrin 5\%) $10 \mathrm{gr} \pm$ Rp.45.000, sedangkan harga salep 2-4 hanya $15 \mathrm{gr}$ hanya \pm Rp.7.500. Obat yang mahal belum tentu memiliki efektivitas terapi yang lebih besar, begitupun dengan obat yang murah belum tentu kurang efektif daripada obat yang mahal. Untuk menilai keefektifan terapi kedua obat tersebut dari segi keberhasilan terapi maupun dari segi ekonomi maka perlu dilakukan pengkajian Analisis Biaya Efektif (ABE). Penilaian Analisis Biaya Efektif dapat memberikan suatu kebijakan dalam menetukan pilihan terapi, sehingga terapi dapat lebih rasional dan efektif.

Rumusan masalah dari penelitian ini adalah Bagaimanakah ABE (Analisis Biaya Efektif) terapi skabies Permetrin 5\% dan Salep 2-4 di Pesantren Miftahul Huda Manonjaya Tasikmalaya. Tujuan dari penelitian yaitu Mengetahui karakteristik pasien skabies berdasarkan kelompok usia, mengetahui tingkat kesembuhan skabies berdasarkan lama terapi, mengetahui efektifitas terapi berdasarkan perhitungan ACER, ICER dan analisis statistik 


\section{Media Informasi}

terhadap hasil terapi yang menggunakan

\section{METODE}

\section{Desain Penelitian}

Penelitian ini merupakan uji klinis dengan Randomized Control Trial (RCT) dan pendekatan Analisis Biaya Efektif (ABE) untuk melihat efektivitas terapi terhadap biaya antara pengobatan permetrin 5\% dan salep 2-4.

\section{Populasi dan Sampel}

Populasi dalam penelitian ini adalah siswa remaja putra (12-25 tahun) yang tinggal dalam 1 kobong di pondok pesantren Miftahul Huda Tasikmalaya yang didiagnosa mengalami skabies. Jumlah populasi yang diperoleh dari penelitian pendahuluan yaitu 24 orang. Pengambilan sampel dalam penelitian ini secara total sampling dengan kriteria sampel yaitu pasien dengan diagnosa skabies tanpa penyakit penyerta.

\section{Waktu dan Tempat Penelitian}

Pengumpulan data dilakukan secara prospektif selama 2 bulan pada September-Oktober 2017 di Pesantren Miftahul Huda Tasikmalaya.

\section{Bahan Penelitian}

Bahan yang digunakan adalah krim pemetrin 5\% dan salep 2-4.

\section{Variabel Penelitian}

Variabel bebas dalam penelitian ini adalah efektivitas pemberian Permetrin $5 \%$ dan Salep 2-4 dilihat dari lama pengobatan, efek samping dan biaya terapi. Variabel terikat dalam penelitian ini adalah penyembuhan klinis berupa hilangnya lesi papul yang disebabkan oleh tungau Sarcoptes scabiei.

\section{Prosedur Pengumpulan Data}

1. Pemeriksaan dilakukan pada santri putra, diagnosa ditegakkan berdasarkan anamnesis dan pemeriksaan fisik. Anamnesis meliputi :

a) Penderita mengeluh gatal terutama di malam hari.

b) Adanya teman atau keluarga serumah yang menderita sakit.

Sedangkan pemeriksaan fisik meliputi :

a) Lokasi lesi pada sela jari tangan, sela jari kaki, telapak tangan, permukaan fleksor pergelangan tangan, siku, ketiak,
Permetrin $5 \%$ dan salep 24.

daerah payudara, daerah garis sabuk, bokong, dan kemaluan.

b) Adanya wujud kelainan kulit berupa papul dan vesikel.

2. Diagnosis skabies ditegakkan berdasarkan diagnosis pasti oleh dokter klinik setempat.

3. Penderita skabies yang pada pemeriksaan fisik didiagnosa mengalami skabies diberikan Informed Consent, dibuat status penderita dengan mencatat identitas, hasil anamnesis dan pemeriksaan fisik.

4. Penderita yang mendapatkan resep krim Permetrin 5\% diberi nomor urut genap dan Salep 2-4 pada penderita dengan nomor urut ganjil.

5. Evaluasi klinis dengan mencatat gejala gatal, intensitas gatal, lesi kulit, efek samping obat pada kunjungan hari ke-8, 15 dan 22, kemudian dibuat evaluasi kesembuhan klinis berdasarkan perbaikan klinik lesi kulit sebagai berikut :

a) Sembuh : bila lesi papul, vesikel hilang $100 \%$

b) Tidak sembuh : apabila lesi papul, vesikel hilang $<100 \%$

7. Pada penderita yang belum sembuh dilakukan pengobatan ulang pada hari ke-8 dan 15.

8. Penilaian biaya terapi yang dilakukan peneliti dilihat dari biaya medik langsung meliputi biaya kunjungan ke dokter dan obat. Sedangkan biaya non medik tidak langsung meliputi biaya transportasi.

\section{Analisis Data}

Efektivitas biaya dilihat berdasarkan Average Cost-Effectiveness Ratio (ACER) dan Incremental Cost-Effectiveness Ratio (ICER). ACER adalah metode yang digunakan untuk menganalisis efektifitas biaya dan menghitung besar biaya yang harus dikeluarkan. Dihitung berdasarkan jumlah biaya pengobatan yang dikeluarkan dibagi dengan efektivitas (lama pengobatan dan persen kesembuhan). Untuk menghitung ACER = Health Care Cost (Rp) / Clinical Outcome (lama pengobatan dan persen kesembuhan). Suatu terapi dikatakan costeffective jika biaya yang dikeluarkan serendah mungkin dengan masa/lama pengobatan secepat mungkin.

Suatu obat dikatakan cost effective apabila mempunyai efektivitas sama tetapi harga obat 


\section{Media Informasi}

lebih rendah atau mempunyai efektivitas lebih tinggi tetapi harga obat sama atau mempunyai nilai ACER lebih rendah (jika efektivitas dan harga lebih tinggi). ICER didefinisikan sebagai

\section{HASIL}

Karakteristik Usia Subjek Penelitian

Angka kejadian skabies pada bulan SeptemberOktober 2017 pada santri putra di Pesantren Miftahul Huda yaitu sebayak 24 kasus. Namun yang dijadikan responden penelitian berjumlah 21 santri putra, dikarenakan 3 orang santri tidak berada ditempat ketika dilakukan penelitian. Pasien dikelompokkan menjadi dua kategori yaitu remaja awal (12-16 tahun) dan remaja akhir (17-25 tahun). Distribusi pasien skabies berdasarkan usia di pondok pesantren Miftahul Huda pada bulan September-Oktober 2017 dapat dilihat pada tabel 1 .

Tabel 1. Distribusi Pasien Skabies Di Pondok Pesantren Miftahul Huda Pada Bulan September-Oktober 2017

\begin{tabular}{lcc}
\hline $\begin{array}{c}\text { Umur Pasien } \\
\text { (Tahun) }\end{array}$ & $\begin{array}{c}\text { Jumlah } \\
\text { (Orang) }\end{array}$ & $\begin{array}{c}\text { Persentase } \\
(\%)\end{array}$ \\
\hline Remaja Awal (12-16) & 16 & 76,2 \\
Remaja Akhir (17-25) & 5 & 23,8 \\
\hline Total & 21 & 99.98 \\
\hline
\end{tabular}

Berdasarkan data yang diperoleh, pasien dapat dikelompokkan berdasarkan terapi yang diterima yaitu kelompok Permetrin 5\% dan Salep 24.

Tabel 2. Gambaran Terapi Skabies Di Pondok Pesantren Miftahul Huda Pada Bulan September-Oktober 2017

\begin{tabular}{lcc}
\hline Keterangan & $\begin{array}{c}\text { Jumlah } \\
\text { (Orang) }\end{array}$ & Persentase (\%) \\
\hline Terapi skabies & & \\
$-\quad$ Permetrin 5\% & 10 & 47,62 \\
- Salep 24 & 11 & 52,38 \\
\hline Total & $\mathbf{2 1}$ & $\mathbf{1 0 0 , 0 0}$ \\
\hline
\end{tabular}

Lama terapi pasien skabies ditentukan berdasarkan persentase (\%) hilangnya lesi dan vesikel.

Tabel 3. Data distribusi lama terapi pasien skabies pesantren Miftahul Huda

\begin{tabular}{ccc}
\hline Lama Terapi & \multicolumn{2}{c}{ Hilangnya Lesi } \\
\cline { 2 - 3 } (Minggu) & Permetrin 5\% & Salep 24 \\
\hline
\end{tabular}

rasio perbedaan antara biaya dari dua alternatif dengan perbedaan efektivitas antara alternatif dan dihitung $\mathrm{ICER}=\Delta \mathrm{biaya} / \Delta$ efek $^{11}$.

\begin{tabular}{lcc}
\hline 1 Minggu & $98 \%$ & $91 \%$ \\
2 Minggu & $100 \%$ & $100 \%$ \\
\hline
\end{tabular}

\section{Analisis Biaya Efektif}

Data kemudian dianalisis dengan metode deskriptif sehingga dapat digambarkan tentang penatalaksanaan skabies dari segi farmakoekonomi serta dampaknya terhadap outcomes terapi.

Tabel 4. Distribusi Biaya Penggunaan Obat Per Terapi Pada Pasien Skabies

\begin{tabular}{|c|c|c|c|}
\hline No & $\begin{array}{c}\text { Kelompok } \\
\text { Terapi }\end{array}$ & $\begin{array}{c}\text { Jumlah } \\
\text { obat/pasien }\end{array}$ & $\begin{array}{c}\text { Biaya } \\
\text { penggunaan } \\
\text { Obat per pasien }\end{array}$ \\
\hline 1. & Permetrin 5\% & 1 Tube & Rp. 50.000 \\
\hline 2. & Salep 24 & 3 Pot & Rp. 15.000 \\
\hline
\end{tabular}

Biaya dokter yang dikeluarkan ketika pasien memeriksakan penyakit untuk kedua kelompok terapi didapat keseragaman biaya yaitu Rp.30.000/pasien untuk setiap kali pemeriksaan

\section{Perhitungan analisis biaya berdasarkan ACER}

Analisis efektifitas biaya dilakukan dengan cara membandingkan biaya penggunaan Permetrin $5 \%$ dan Salep 24 per hari dengan nilai efektifitas atau outcomes klinis berdasarkan data yang diperoleh selama penelitian. Efektifitas biaya berdasarkan dengan menggunakan rumus Average Cost Effectiveness Ratio (ACER) yang dihitung berdasarkan jumlah biaya total yang dikeluarkan pasien skabies terhadap efektifitas penggunaan. Pada penelitian ini ACER berguna menggambarkan total biaya terapi atau intervensi dibagi outcomes klinis. Semakin rendah nilai ACER, maka semakin cost effective karena dengan biaya perawatan kesehatan yang rendah mampu memberikan hasil terapi yang lebih tinggi. Secara konsep, cost effectiveness analysis sebagai bentuk evaluasi ekonomi yang berpotensi sebagai alat pembuatan prioritas berdasarkan parameter efisiensi. ${ }^{9}$ Hasil analisis Cost Effectiveness Permetrin 5\% dan Salep 24 terhadap biaya penggunaan dapat dilihat pada tabel 5 :

DOI: $10.37160 /$ bmi.v15i2.432 


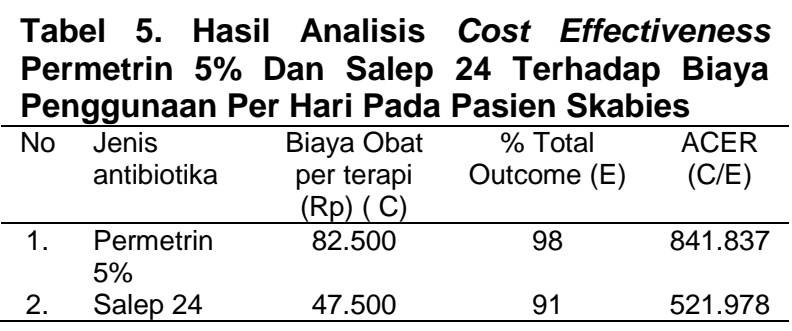

\section{Perhitungan Analisis Biaya Berdasarkan ICER}

Perhitungan ICER dilakukan karena obat permentrin $5 \%$ memiliki biaya yang tinggi dibandingkan dengan salep 2-4 dan efektivitasnya juga lebih tinggi. Oleh karena itu perlu dilakukan perhitungan ICER untuk menghitung biaya peningkatan 1 unit efektivitas obat termahal dibandingkan obat termurah. Berikut hasil perhitungan ICER antara permetrin $5 \%$ terhadap salep $2-4$.

Perhitungan ICER :

$=$ (Biaya obat tinggi - biaya obat rendah) /

(\%outcome tinggi-\%outcome rendah)

$=(82.500-47.500) /(98-91)$

$=5.000$

\section{Hasil Perhitungan Statistik}

Analisis statistik dalam penelitian ini menggunakan analisis statistik bivariat untuk ada tidaknya perbedaan terapi Permetrin 5\% dan Salep 2-4 terhadap keberhasilan terapi penyakit skabies. Analisis statistik menggunakan uji $\mathrm{T}$ independent, nilai $\mathrm{P}$ value yaitu 0,2 .

\section{PEMBAHASAN}

\section{Karakteristik Usia Subjek Penelitian}

Hasil penelitian menunjukkan bahwa berdasarkan rentang usia kelompok pasien remaja awal memiliki jumlah yang terbanyak yaitu 16 pasien $(6,2 \%)$, sedangkan remaja akhir 5 pasien $(23,8 \%)$. Pasien remaja awal lebih banyak dari pada remaja akhir menandakan bahwa pengetahuan tentang penyakit skabies dan hygiene perorangan masih kurang. Hal ini sesuai dengan hasil penelitian Fadia dan Saleha (2014) yang menyebutkan bahwa ada hubungan antara pengetahuan dan hygiene perorangan dengan terjadinya scabies. ${ }^{12}$
Skabies adalah penyakit yang disebabkan oleh ektoparasit yang umumnya terabaikan sehingga menjadi masalah kesehatan yang umum di seluruh dunia, dapat menjangkiti semua orang pada semua umur, ras dan level sosial ekonomi. ${ }^{13}$

\section{Data terapi pasien}

Berdasarkan data pada tabel 4.2 bahwa pasien yang mendapatkan terapi permetrin $5 \%$ yaitu 10 orang $(47,62 \%)$, sedangkan yang mendapatkan terapi salep 2-4 yaitu 11 orang (52,4\%). Persentase lesi dan vesikel pada setiap pasien homogen, maka dokter dapat meresepkan obat Permetrin 5\% atau salep 2-4.

Gejala klinis yang khas pada pasien skabies ada 3 yaitu adanya kunikulus, muncul papula eritematosa dan adanya rasa gatal13. Pengobatan skabies dikatakan gagal jika gejala gatal malam hari menetap bahkan memburuk setelah 2 minggu. ${ }^{16}$ Jika dilihat dari tabel diatas penggunaan permetrin 5\% dan salep 24 efektif. Pada minggu ke-1 menunjukkan keberhasilan terapi 98\%, sedangkan Salep 2-4 keberhasilan terapi tidak jauh berbeda yaitu $91 \%$. Mekanisme kedua obat ini yaitu sama-sama dapat membunuh tungau dewasa. Perbedaan diantara kedua obat ini yaitu Permetrin 5\% dapat membunuh tungau dewasa, larva dan juga membunuh telur. Sedangkan salep 2-4 tidak dapat membunuh telur tungau. Hal tersebut yang menyebabkan perbedaan aturan pakai kedua obat, Permetrin 5\% cukup digunakan satu kali selama satu hari, lalu dikontrol satu minggu kemudian. Sedangkan Salep 2-4 digunakan satu kali sehari selama tiga hari berturut-turut agar dapat membunuh semua larva, karena telur dapat menetas setelah 3 hari. ${ }^{17}$

Follow up mengenai tingkat kesembuhan pasien hanya dilakukan sebanyak 2 kali yaitu pada hari ke 8 dan hari ke 15, karena pada hari ke 15 tingkat kesembuhan pasien $100 \%$ pada setiap pilihan terapi.

\section{Analisis Biaya Efektif}

Penggunaan Permetrin 5\% pada setiap pasien cukup diberikan 1 tube karena hanya digunakan 1 kali dalam sehari. Sedangkan Salep 2-4 setiap pasien diberikan sebanyak 3 pot, karena penggunaannya selama 3 hari berturut-turut. 


\section{Media Informasi}

Prinsip pengobatan skabies adalah menggunakan skabisida topical. Syarat skabisida ideal adalah efektif terhadap semua stadium tungau, tidak toksik atau menimbulkan iritasi, tidak berbau, serta tidak menimbulkan kerusakan atau mewarnai pakaian, dan mudah diperoleh. Syarat lainnya adalah harga skabisida cukup murah karena penderita skabies umumnya dari golongan ekonomi lemah. ${ }^{18}$ Dari hasil penelitian didapatkan bahwa walaupun salep 2-4 yang diberikan jumlahnya lebih banyak dari pada salep Permetrin 5\%, namun biaya penggunaan Permetrin 5\% lebih tinggi dari Salep 2-4. Penggunaan kedua salep ini yaitu sama, tidak hanya dioleskan pada bagian yang sakit, namun dioleskan pada seluruh bagian tubuh.

\section{Perhitungan Analisis Biaya Berdasarkan ACER}

Dari hasil ACER penggunaan obat skabies menunjukkan bahwa kelompok yang costeffective adalah Salep 2-4 yaitu 512.978 sedangkan yang tidak cost-effective adalah Permetrin $5 \%$ yaitu 841.837 . Terlihat dari hasil ACER bahwa kelompok Permetrin 5\% lebih tinggi biayanya dibandingkan kelompok Salep 24. Dari hasil perhitungan maka obat Salep 2-4 lebih murah dari pada Permetrin 5\%.

\section{Perhitungan Analisis Biaya Berdasarkan ICER}

Interprestasi dari perhitungan diatas yaitu pemilihan obat Permetrin 5\% terdapat penambahan biaya 5.000 untuk peningkatan 1 unit efektivitas.

\section{Hasil perhitungan statistik}

Analisis statistik dalam penelitian ini menggunakan analisis statistik bivariat untuk ada tidaknya perbedaan terapi Permetrin 5\% dan Salep 24 terhadap keberhasilan terapi penyakit skabies. Analisis statistik menggunakan uji $\mathrm{T}$ independent, nilai $\mathrm{P}$ value yaitu 0,2 . Hasil tersebut menunjukkan bahwa tidak terdapat perbedaan antara terapi Permetrin 5\% dan Salep 2-4 terhadap keberhasilan terapi skabies. Semua skabisida topikal memiliki prinsip penggunaan yang sama dan harus dipatuhi oleh penderita. Efektivitas terapi tidak ditentukan dari harga obat yang mahal tetapi dipengaruhi oleh berbagai faktor yaitu diagnosis, ketepatan terapi topikal, dosis skabisida, dan waktu pemakaian obat. ${ }^{18}$

\section{KESIMPULAN}

Tingkat kesembuhan rata-rata pasien skabies yang diterapi Permetrin 5\% yaitu 98\% dan Salep 2-4 yaitu $91 \%$ dengan lama terapi 1 minggu, sedangkan lama terapi 2 dan 3 minggu tingkat kesembuhan kedua terapi ini yaitu $100 \%$. Berdasarkan hasil perhitungan ACER dan ICER terapi skabies yang paling efektif yaitu Salep 24 dengan nilai ACER 521.978 dan ICER 5000 untuk peningkatan 1 unit efektivitas Permetrin 5\% terhadap Salep 2-4. Hasil analisis statistik menunjukkan bahwa tidak terdapat perbedaan antara terapi Permetrin 5\% dan Salep 2-4 terhadap keberhasilan terapi Skabies.

\section{SARAN}

Melakukan penyuluhan langsung ke setiap pondok pesantren mengenai pencegahan dan penanganan skabies, dapat dilakukan dengan berkoordinasi dengan Dinas Kesehatan setempat atau Puskesmas. Metode yang dapat digunakan yaitu metode ceramah dengan menggunakan media leaflet atau booklet.

\section{DAFTAR PUSTAKA}

1. Setyaningrum, Y. I. Seminar Nasional $X$ Pendidikan Biologi FKIP UNS Seminar Nasional X Pendidikan Biologi FKIP UNS; 2012

2. Chowsidow O. Skabies, The New England Journal Of Medicine. 35,1-16;2006

3. Bandi K.M. \& Saikumar C., Sarcoptic mangea zoonotic ectoparasitic skin disease. Journal of Clinical and Diagnostic Research 4839. 1-2; 2012

4. Wong SSY, Woo PCY, Yuen K. Skabies Provided a Clue to Diagnosis, Unusual laboratory findings in a case of norwegia, .J. Clin. Microbiol; 3(5):2542. diunduh dari: http://icm.asm.org/content/43/5/2542.full.pdf; 2005+html (17)

5. Cordoro K.M. \& Iston D.M. Skabies. In: Hogan D et.al., eds. E-Medicine World Medical Library [online]. (http:www.emedicine.com/derm/topic 382.htm); 2012

6. Akmal, S. C. \& Semiarty, R. Artikel Penelitian Hubungan Personal Hygiene Dengan Kejadian Skabies Di Pondok Pendidikan 
Islam Darul Ulum, Palarik Air Pacah, Kecamatan Koto Tangah Padang 2(3), 164167; 2013

7. Thomas, J., Carson, C. F., Peterson, G. M., Walton, S. F., Hammer, K. A., Naunton, M., Baby, K. E. Review Article Therapeutic Potential of Tea Tree Oil for Skabies, 94(2), 258-266. http://doi.org/10.4269/ajtmh.140515; 2016

8. WHO, WHO Guide to Cost Effectiveness Analysis, ISBN 924154601 8, WHO, Geneva; 2003

9. Audhah, N. Al. Skabies risk factor on students of Islamic boarding school (Study at Darul Hijrah Islamic Boarding School, Cindai Alus village, Martapura Subdistrict , Banjar District, South Kalimantan ). 4(1), 14-22; 2012

10. Eka N.C. Uji Banding Efektivitas Krim Permethr in 5\% dan Salep 2- 4 pada Pengobatan Skabies. Skripsi. Fakultas Kedokteran Universitas Diponegoro Bagian Kulit dan Kelamin. Semarang; 2004

11. Andayani. T.M. Farmakoekonomi, Prinsip dan Metodologi. Bursa Ilmu .Yogyakarta; 2013

12. Wolff K, Goldsmith LA, Katz SI, Gilchrest BA, Paller AS, Leffell DJ.Fitzpatrick's.
Dermatology In General Medicine. 7th edition. Mc Graw Hill. New York; 2008

13. Raza N. Qadir S. N. R., Agna H. Risk faktor for skabies among male soldier in Pakistan: case-control study. Eastern Mediterranean Health Journal 15, 1-6; 2009

14. NHS. Guidelines for the Management of Skabies. Highland; 2009

15. Fadia A.R, Saleha S. Prevalensi Skabies dan Faktor-faktor yang Berhubungan dii Pesantren X Jakarta Timur.eJKI. Fakultas Kedokteran UI; 2014

16. Fakhrena F. Perbandingan efektivitas terapi kombinasi salep 2-4 dan sabun sulfur $10 \%$ dengan salep 2-4 tunggal sebagai pengobatan skabies di pondok pesantren bait Qur'ani Ciputat. Tanggerang Selatan. Skripsi Prodi Pendidikan Dokter FKIK Universitas Syarif Hidayatullah. Jakarta; 2015

17. Iskandar T. Masalah Skabies pada Hewan dan Manusia serta Penanggulangannya, WARTAZOA Vol 10; 2000

18. Sungkar.S. Skabies, Etiologi, Patogenesis, Pengobatan, Pemberantasan dan Pencegahan, Penerbit Fakultas Kedokteran UI. Jakarta ; 2016 